of funding and the more specific funding of the research grant surely should have been an essential part of the book, but it seems that Mr Carswell does not think so. Since he was placed so well as an observer - first as an official at the Treasury, and at the Department of Education and Science, and, subsequently, as Secretary to the UGC - this seems a particular pity.

Then it is illuminating to view the British universities as part of an international scene. Mr Carswell makes little attempt to do so. As an example, when I was a ViceChancellor I learned from my American counterparts, the Presidents of the "research" universities, that the diverse funding which they enjoyed was no sure safeguard against the economic ill-wind. When such a wind blows on a national scale then there are few, if any, funding sources that are immune to it.

It would, too, have been useful to have had from someone with Mr Carswell's experience a rather more critical discussion of how well-suited the UGC is to its present tasks, particularly with Lord Croham about to report on this matter. Though, like most academics, I am a great admirer of the UGC system and those who have operated it over the years, my own view is that it is quite unsuited to its main responsibilities; namely, the getting and the planning of the spending of over $£ 1,000$ million a year. To start with it is grossly understaffed, both in terms of quality and quantity, to carry out such work.

The principal event of the two decades $\mathrm{Mr}$ Carswell is concerned with was, of course, the post-war "bulge" reaching the universities and the consequent Robbins Report and general expansion of the higher education system. Mr Carswell pays tribute to the Robbins Report as "one of the great state papers of this century", and rightly so; one of its many virtues was that it contained so much information that if you did not like its analysis or its conclusions then you could invent your own.

Mr Carswell has a weakness for the purple - well, lavender - passage. His concluding paragraph is:
The state and the universities are like a discontented couple who cannot live without each other: he rich, busy, self-important, preoccupied with the office; she proud, independent and in her own opinion beautiful. The statehusband will always complain about her extravagance and inconstancy, and the universitywife will endlessly denounce his stinginess, jealousy and philistinism. Her parting words in the endlessly renewed argument will be that she knows he has a mistress - "and very common she is'. But they would not dream of parting: because of the children.

I think it quite wrong to interpret the relationship of the government and the universities as one of conflict. Even at the present troubled moment, as troubled as any moment in the past 30 years, I do not see the damage which is unquestionably being done to the universities by government cuts as a considered attack on the academic world. All that has happened, surely, is that we have a government committed to reducing public expenditure which has misjudged the serious longterm consequence of damage to the universities, and which believes, correctly if sadly, that the universities will not have wide public support. This last is due in part to the relatively small scale of the British university system with, in turn, so few graduates in the community; but it is due much more to the damaging antics of students in the period Mr Carswell describes, and also to the absurd misconception of university as ivory tower.

A university's first duty is indeed to preserve, create and transmit scholarship, but the modern university has little or no problem in reconciling this to its more immediate responsibilities to the community. One of my Canadian vice-cancellarial colleagues exaggerated when he said that "a university today does not know whether it is an ivory tower, a frontier post or a service station". The fact is that it has to manage to be all three; but that, again, is not a problem discussed in this book.

Sir Alec Merrison, Vice-Chancellor of the University of Bristol from 1969 to 1984, and a member of the Advisory Board for the Research Councils from 1979 to 1983, is a Director of Lloyds Bank plc and Chairman of the Western Provident Association Ltd, Culverhouse, Culver Street, Bristol BS1 5JE, UK

\section{Cutting changes in the mind}

\section{Stuart Sutherland}

Great and Desperate Cures: The Rise and Decline of Psychosurgery and Other Radical Treatments for Mental Illness. By Elliot S. Valenstein. Basic Books: 1986. Pp.338. \$19.95.

THE mentally ill have always been treated with a savagery normally reserved for alien races. The chains that Pinel struck from his patients in the Salpêtrière were soon replaced by more insidious assaults devised by the medical profession. Within the past hundred years, mental patients have been subject to prolonged cold douches and other forms of hypothermia; they have been deliberately infected with malaria; they have been plastered with ointments to produce fevers and pustules of pus; they have had large quantities of horse serum injected into their spinal cord in order to cause meningitis; their endocrine glands have been removed; their teeth and tonsils have been taken out on the grounds that they might be harbouring infections; and female patients have had their cervices excised. More recently, mental patients have been subjected to insulin and metrazol therapies which produce convulsions and coma, and, as a sideeffect, fractured and dislocated bones. None of these treatments is known to have brought any benefit nor did they have any scientific justification, though their proponents were not slow to support them with naive and unsubstantiated theories of the nature of mental illness.

Great and Desperate Cures raises the question of how far the mutilation of the mentally ill in the name of medicine has continued into recent years. Most of the book is a history of psychosurgery, that is surgery undertaken on parts of the brain not known to be diseased or damaged with the intention of changing the patient's psychological state.

The first to undertake such surgery was Egas Moniz, a Portugese neurologist whose ambition exceeded his talent. He invented prefrontal lobotomy, an operation in which the nerve fibres between the prefrontal lobes and the remainder of the brain are severed. It is now known that these fibres connect the prefrontal cortex to the limbic system, which is implicated in the control of emotion, but Moniz was inspired to undertake the operation by witnessing two monkeys which, it was claimed, had been made placid by lesions to their frontal lobes. Even this justification turns out to have been erroneous, since in fact one of the monkeys became more irascible after the operation. This fact was conveniently forgotten by one of 
the experimenters, John Fulton, a prestigious American neurophysiologist, in an attempt to gain credit for initiating psychosurgery. Valenstein presents a good case for believing that Moniz's main motive was to achieve in his declining years the recognition that a rather mediocre career had otherwise failed to bring, by gambling on the success of an operation so drastic that nobody else would dare to perform it.

It was Walter Freeman, a professor at George Washington University, who in 1936 introduced prefrontal lobotomy to the United States. Over the next 30 years he was its main advocate and conducted over 2,000 operations, paying seemingly little attention to the type of mental illness from which his patients suffered. He was a buccaneer who combined coldness with considerable personal courage. $\mathrm{He}$ invented transorbital lobotomy, a procedure that could be carried out in a few minutes and without an anaesthetic. An ice-pick or any other instrument that came to hand was used to pierce the orbit of the eye and to mash up the adjacent parts of the frontal lobe. Freeman would perform the operation at a whim in his own office with almost no antiseptic precautions. $\mathrm{He}$ launched a crusade to bring this simple but unaesthetic operation to the overcrowded mental hospitals of the United States, tirelessly going from one to another to demonstrate how it was done and making deliberate use of the press to gain publicity for his claims.

Valenstein attributes the inception and growth of psychosurgery to two main causes. The first was the ambition of its proponents, ambition which in Moniz's case the Nobel Prize Committee to its shame rewarded with the 1949 prize for medicine. Second was the economic problem created by the large number of patients in mental institutions: one report even counted as an economic saving the reduction in patients caused by deaths in the operation. But a third reason must surely have been the frustration felt by doctors in the face of the sheer misery of mental illness and the knowledge that there was little or nothing they could do to alleviate it.

In fact, as soon as other methods of therapy became available, psychosurgery lost its popularity. In the 1960 s it was replaced by the widespread use of electroconvulsive therapy and by the new psychotropic drugs. Moreover, the recognition that a long stay in a mental hospital hurt the patient even more than it did the tax-payer was beginning to reduce the number of long-stay patients and hence the economic argument for psychosurgery was weakened.

Valenstein avoids moral judgements, but there is one respect in which the initiators of psychosurgery were clearly guilty. Having begun, almost on impulse, to

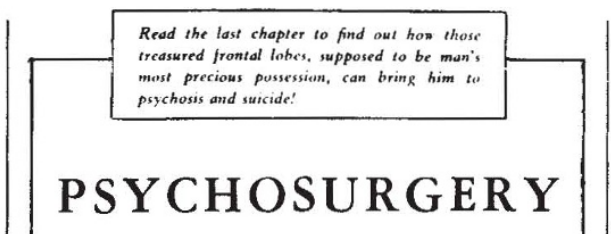

was a control group, he grunted and said, "We don't need that, take it out. I'm in control here".

Regrettably Valenstein does not present a systematic review of the effects of psychosurgery. Some reports, particularly those of Freeman, suggest that it may help some people and two independent studies have reached the same conclusion. But its effects appear to vary unpredictably from person to person and there is no question that it can do terrible harm. Unfortunately it was not always used as a last resort and there are pathetic cases in which it has turned previously cheerful adolescents into zombies.

The question of the effects of psychosurgery is by no means an academic one, for several hundred such operations a year are still being performed in the West. Those on mental patients rarely receive any publicity, but in the United States and elsewhere prisoners have received psychosurgery in order to reduce violent behaviour or rid them of sexual compulsions, and several operations have been undertaken on recalcitrant children. Some of these operations were performed with consent granted in return for parole; others, notably those on children, without consent.

Valenstein's concluding chapter is too short and too hurried. He presents his story as a cautionary tale and points to the rapid increase in the United States of coronary by-pass operations, many of which are being carried out on patients who, according to a recent large-scale study, can derive no benefit from them. Careful research is clearly not a complete answer, because it can always be ignored by over-enthusiastic or avaricious surgeons. Valenstein himself proposes that new surgical procedures should be subject to the same restrictions as new drugs: despite the outcry to be expected from surgeons, this would appear to be only common sense. Such procedures would only be carried out on a large scale after research (initially on animals) had demonstrated that their benefits outweighed their risks. Valenstein is aware that surgeons would argue that such restrictions would deprive some people of an operation from which they might benefit, but they would also prevent people who would not benefit from being mutilated; moreover, the opinion of a committee is likely to be more dispassionate than that of the surgeon who wishes to practise the operation.

Despite Valenstein's puzzling failure to deal fully with the effects of psychosurgery and the ethical issues it raises, his well, often very well, written account of its inception and hey-day is both fascinating and salutary.

Stuart Sutherland is Director of the Centre for Research on Perception and Cognition, University of Sussex, Brighton BN1 9QG, UK. 